\title{
The Reflection of Family Function and Premarital Sex Behavior on Art Community
}

\author{
Siti Nur Djannah ${ }^{1,2}$, Bhisma Murti ${ }^{1}$, Yayi Suryo Prabandari ${ }^{3}$, Sapja Anantanyu ${ }^{3}$ \\ ${ }^{1}$ Department of Public Health, Sebelas Maret University, Surakarta, Indonesia \\ ${ }^{2}$ Department of Public Health, Universitas Ahmad Dahlan, Yogyakarta, Indonesia \\ ${ }^{3}$ Department of Public Health, Gajah Mada University, Yogyakarta, Indonesia
}

\begin{tabular}{l}
\hline \hline Article Info \\
\hline Article history: \\
Received Mar 13, 2016 \\
Revised May 12, 2016 \\
Accepted May 27, 2016 \\
\hline
\end{tabular}

\section{Keyword:}

Family Function Premarital Sex Behavior Art Community

\begin{abstract}
The premarital sex behavior in Indonesia based on SKRRI 2012 is a problem which requires the serious concern because it ensues unwanted pregnancy, then take the abortion and carries the venereal disease, therefore the teenager will lose their future. The risk factors related to premarital sex behavior affected by external factor such as the relationship between parents and adolescense. This is occurred in adolescenses who join in an art community of Jathilan, which is Paguyuban Turonggo Wiro Budoyo Wirobrajan Yogyakarta, where the management explains that the members do free sex and they cannot do the family function especially in educating the reproduction health for teenager. This research aims to find out the reflection of family function and reproduction health of and sex in teenager of TWB Community.This research is quantitative descriptive support by qualitative. The data collecting technique is purpose sampling. The research subject is Community members of Seni Jathilan Turongo Wiro Budoyo, total 47 members. The reflection of family function in teenager of TWB community member, majority of family do not give the education function, affection function, protection function, and socialization function adolescense reproduction health, and the reflection teenager sex of TWB Community is majority doing free sex.
\end{abstract}

Copyright $\odot 2016$ Institute of Advanced Engineering and Science. All rights reserved.

\section{Corresponding Author:}

Siti Nur Djannah,

Doctoral Student Department of Public Health,

Sebelas Maret University,

Surakarta, Indonesia.

Email: njannahsitti_fkmuad@yahoo.com

\section{INTRODUCTION}

A family is a place to introduce the society for children and it holds the main duty toward children socialization. Through the socialization, children get social skill, emotional and cognitive learning in order to function in community [1]. According to Erwin (2005) the communication between parents and their children about sexuality aims to give the actual knowledge and opinion and give the valid and factual information to children especially about sexuality, therefore the children have the comprehensive knowledge of sexuality and they do not do the sex abuse includes sex before marriage [2].

The delivering information process through trust, open and positive support for children is an effective communication in order to adolescence can receive the information well [3]. The tendency of bad 
sex recently is influenced by wrong education of the parents. Majority the parents do not inform about sex and reproduction health for their children, because afraid of it will increase the number of free sex. Parents' also considering that sex is unnecessary subject to be discussed. The less of sex education bring the children seeks information from other source and it damages themselves [4].

The Demography Survey and Indonesian Health of adolescence reproduction health or Survei Kesehatan Reproduksi Remaja Indonesia (SKKRI) 2012 found that percentage of adolescence age 20-24 years old discuss about the reproduction health problem with their friends is $66.9 \%$ (girls) and $61.2 \%$ (boys). Percentage of adolescent (boys and girls) age 15-24 years old that are in relationship is higher in SDKI. In 2012, the component of Adolescence Reproduction Health or Kesehatan Reproduksi Remaja (KRR) is higher than 2007 year, 85\% and $72 \%$ for boys, $85 \%$ and $77 \%$ for girl. Perception percentage trend that girl should keep the virginity decrease than year 2007, both for girls and boys. Besides that, the dating activity involve hold the hands ( $72 \%$ girls and $80 \%$ boys), kissing ( $48 \%$ boys and $30 \%$ girls), touch the sensitive spot (30\% boys and $6 \%$ girls), sex before marriage is $83.7 \%$ for the love reason [5].

The survey result of Adolescence Reproduction of Health Indonesian or Survei Kesehatan Reproduksi Remaja Indonesia (SKRRI) 2012 years, about sex before marriage of University student in Semarang in September 2002 for 1000 respondents that is 500 respondents from various Universities in Semarang said that activity of dating is more than chatting, hugging, and kissing. They also do petting $25 \%$, and even sexual intercourse [6].

One of sub district of Yogyakarta, Wirobrajan, there are adolescence join in a community of senijathilan, name Turonggo Wiro Budoyo, which based on preliminary study, the interview with the leadership in April 2015, explained that majority of the members doing free sex. Some of them get pregnant and get marriage in young age. The preliminary study found, one of supported factor is social effect as parents. According to them, the parents do not give the educational function, social function, affection function, economical function and, protection function yet, which related to reproduction health. It causes more closes with their mate.

Based on the reasons, it is interesting to be analyzed about the detail and actual empirical information from the analysis unit or research related to teenager and such social units in society, that is the reflection of family function and sex of teenager in Seni Jathilan TWB Community, Yogyakarta. This research aims to find out the reflection of family function (includes affection function, education function, socialization function, and protection function), and premarital sex of TWB, which join in an art community, seni jathilan TWB.

\section{RESEARCH METHOD}

This research applied quantitative descriptive support by qualitative. The data collecting technique used by researcher is purpose sampling technique. The research subject is the adolescence in art community of Jathilan Turonggo Wiro Budoyo, place in Wirobrajan, Yogyakarta and age 12-24 years old. Total members of TWB are 47.

\section{RESULTS AND ANALYSIS}

\subsection{Univariate Result}

\subsubsection{Respondent Characteristic}

Based on the Table 1, can be explained that the teenager of TWB Community majority are 17 years old $(21.3 \%)$, and most of them graduated from Senior High School (23.4\%). 
Table 1. The Characteristic of Respondent

\begin{tabular}{lcc}
\hline \multicolumn{1}{c}{ Characteristics } & $\mathbf{N}$ & $(\boldsymbol{\%})$ \\
\hline Age & 1 & \\
13 years old & 2 & 2.1 \\
15 years old & 5 & 4.3 \\
16 years old & 10.6 \\
17 years old & 61.3 \\
18 years old & 6 & 12.8 \\
19 years old & 6 & 12.8 \\
20 years old & 6 & 12.8 \\
21 years old & 1 & 2.1 \\
22 years old & 2 & 4.3 \\
23 years old & 3 & 6.4 \\
24 years old & 5 & 10.6 \\
Educational level & & \\
a. Unpassed elementary school & 1 & 2.1 \\
b. Junior high school first grade & 3 & 64 \\
c. Junior high school second grade & 1 & 2.1 \\
d. Junior high school third grade & 3 & 6.4 \\
e. Graduated from JHS & 11 & 23.4 \\
f. Senior high school second grade & 6 & 12.8 \\
g. Senior high school third grade & 4 & 8.5 \\
h. Graduated from SHS & 2 & 4.3 \\
i. Special Skill High School third grade & 4 & 8.5 \\
j. Graduated from SSHS & 6 & 12.8 \\
k. Strata 1 of University & 6 & 12.8 \\
Total & 47 & 100.0 \\
\hline & & \\
& & \\
\hline
\end{tabular}

\subsubsection{Family Function}

Based on Table 2 in family educational function, can be found that majority of family do not discuss about sex problem with the teenager $(63.8 \%)$, the family do not give information about adolescent problem $(55.3 \%)$, and the family do not explain about adolescent process $(61.7 \%)$.

Tabel 2. Family Educational Function

\begin{tabular}{clccc}
\hline & \multicolumn{1}{c}{ Indicator } & Respond & Frequency & \% \\
\cline { 2 - 5 } & Discussion of sexual problems & Yes & 17 & 36.2 \\
Educational & & No & 30 & 63.8 \\
Function & Adolescent Information & Yes & 21 & 44.7 \\
& & No & 26 & 55.3 \\
& Adolescent process & Yes & 18 & 38.3 \\
& Total & No & 29 & 61.7 \\
& & & 47 & 100 \\
\hline
\end{tabular}

Based on Table 3 in family protection function. can be found that majority of family is not protective and majority of family give the knowledge about religion and norm (66\%).

Table 3. Family Protection Function

\begin{tabular}{clccc}
\hline & \multicolumn{1}{c}{ Indicator } & Respond & Frequency & $(\%)$ \\
\cline { 2 - 5 } Protection & Protection function & Yes & 13 & 27.7 \\
function & & No & 34 & 72.3 \\
& Keeping religion and norms & Yes & 31 & 66 \\
& No & 16 & 34 \\
& Total & & 47 & 100 \\
\hline
\end{tabular}

Based on Table 4 in family socialization function, can be found that majority of family do not give the children's need $(87.2 \%)$. family do not give the control $(57.4 \%)$, family do not give the think of future (53.2\%) and do not discuss about sex with parents (78.7\%). Based on Table 5 can be found that $48 \%$ respondent is not warm and kind with family, $68.1 \%$ respondent do not get concern about their problem, and $57.4 \%$ family give negative view (forbidden) about sex. 
Table 4. Family Socialization Function

\begin{tabular}{clccc}
\hline & \multicolumn{1}{c}{ Indicator } & Respond & Frequency & $(\boldsymbol{\%})$ \\
\cline { 2 - 5 } & \multirow{2}{*}{ Children' need } & No & 41 & 87.2 \\
& & Yes & 6 & 12.8 \\
Socialization & Control & No & 27 & 57.4 \\
function & & Yes & 20 & 42.6 \\
& \multirow{2}{*}{ Think of future } & No & 25 & 53.2 \\
& & Yes & 22 & 46.8 \\
& Discussion about sex with parents & No & 37 & 78.7 \\
& & Yes & 10 & 21.3 \\
& Total & & 47 & 100 \\
\hline
\end{tabular}

Table 5. Family Affection Function

\begin{tabular}{|c|c|c|c|c|}
\hline \multirow{8}{*}{$\begin{array}{l}\text { Affection } \\
\text { function }\end{array}$} & Indicator & Respond & Frequency & $(\%)$ \\
\hline & \multirow{2}{*}{ Warmth and kindness } & No & 23 & 48.9 \\
\hline & & Yes & 24 & 51.1 \\
\hline & \multirow{2}{*}{ Concerning about the problem } & No & 32 & 68.1 \\
\hline & & Yes & 15 & 31.9 \\
\hline & \multirow{2}{*}{ Negative view about sex } & No & 27 & 57.4 \\
\hline & & Yes & 20 & 42.6 \\
\hline & Total & & 47 & 100 \\
\hline
\end{tabular}

\subsubsection{The Premarital Sex of Behavior}

The Premarital Sex of Behavior in Jathilan TWB art community as Table 6. From Table 6, the reflection of teenager sex in TWB community, majority do free sex $(68.08 \%)$, then sequentially masturbation $(10.63 \%)$, touching the sensitive spot $(8.51 \%)$, holding hands $(6.38 \%)$, kissing $(4.25 \%)$ and hugging $(2.12 \%)$.

Table 6. The Premarital Sex of Behavior in Jathilan TWB Art Community

\begin{tabular}{clcc}
\hline No & \multicolumn{1}{c}{ Level of sex } & Total & $(\boldsymbol{\%})$ \\
\hline 1 & Masturbation & 5 & 10.63 \\
2 & Holding hands & 3 & 6.38 \\
3 & Hugging & 1 & 2.12 \\
4 & Kissing & 2 & 4.25 \\
5 & Touching sensitive spot & 4 & 8.51 \\
6 & Sex intercourse & 32 & 68.08 \\
& Total & 47 & 100 \\
\hline
\end{tabular}

\subsection{Qualitative finding}

Based on deep interview with teenager of TWBCommunity member who do sex intercourse, find out as:

\subsubsection{Family function}

The effect of family toward TWB teenager sex can be found as follow.

Informant 1:

A: "besides effect from friend, is there family effect?"

B: "yes, there is. I feel lonely at home, my parents on work."

Informant 2:

A: "How about your parent's harmony?"

$B$ : "They are frequently on quarrel"

A: "Is it affecting your life?"

B: "definitely yes, Miss."

A: "What do you feel?"

B: "I feel bored."

Informant 3:

A:since when you live oneself?"

$B$ : "I do not know who my father is, my mother marry four times. I just live with her until in fifth grade of elementary school, after then I leave home and become street musician. 
Informant 4

A: How is your life hood at home? Is there any problems?

$B$ : yes, there are so many problems like family and economic problems. I often discuss about sex with my

friends and I feel more enjoy it.

Informant 5

A: Do you know about mimpibasah before?

$B$ : not yet, I know it from friend, I am not so close with my parents.

Informant 6

A: do your parents explain about reproduction organs function?

$B$ : have not

A: so where do you get the information from?

B: from friends, Miss.

Informant 7:

A: Do your parents enlighten you about mimpibasah?

$B:$ No, never

Informant 8:

A: According to you, how about religiousness of your parents?

$B$ : sometimes I see my father do the pray but my mother is never

Based on the interview with teenager who do free sex above, the teenager feel loneliness because their parents are too concern on work, unharmonious relationship in their family, broken home bring them leave home, feel unclosed with parents, never discuss with their family and they lose the religious sample at home. This drives teenager becomes so much closed with their mate and get reproduction information as wet dream from them. They also solve their sex problem based on information from their friends.

\subsubsection{The Premarital Sex of Adolescense}

follow.

The deep interview finding with teenager of TWB Community Member who do free sex is as Informant 1:

A: "What do you do through dating? Holding hands? Do you get pregnant after having sex?"

B: "I did holding hand when I was in primary high school. I do sex intercourse when I was in Senior High school but never get pregnant."

Informant 2:

A: "What do you do through dating?"

B: "I do having sex"

Informant 3:

A: "What do you do through dating?"

B: "I do everything"

A: "Do you have a sex?"

B: "Yes, I do, about twice I did it."

A: "Do you feel afraid doing free sex?"

B: "I do feel afraid but I can't control myself."

Informant 4:

A: "Have you ever done free sex?"

B: "Yes I have."

A: Did you use condom?"

B: "Never"

A: "What is your reason doing that?"

B. "Because of love. I do love him so much."

Based on the quote of interview above, it can be found that there are teenager of TWB Community Members do sex intercourse through their dating. The reason they do free sex because they can't control their selves and because of love.

\subsection{Discussion}

Based on research result, find the reflection of family function in TWB Community Member who do free sex, majority insufficient. The function involves education function, as known that majority of family do not discuss about sex with adolescense (63.8\%), the family do not give information about adolescent $(55.3 \%)$ and the family do not explain about adolescent process $(61.7 \%)$. Therefore, the protection function, majority

IJPHS Vol. 5, No. 2, June 2016: 176-182 
of family are not protective $(72.3 \%)$, and majority of family do not give the knowledge how to keep the religion and norm (44\%). It also happened in family socialization function, such as majority of family do not give the children necessary $(87.2 \%)$, family do not give the control $(57.4 \%)$, and do not give the think of future $(53.2 \%)$, they do not discuss about sex with their parents $(78.7 \%)$. Then the affection functions also insufficient. It finds out that $48.9 \%$ respondents feel do not get the warmth and comfortable in their family, $68.1 \%$ respondents do not get the attention about their problems, and $57.4 \%$ family give the negative view (forbidden) about sex.

It is supported by deep interview result conducted to respondents find out that majority respondents do not feel comfortable live at home because their family is not in harmony, then disability of parents in giving education health learning. It causes teenager get closer and have more time with their mates.

This research appropriate to research which conducted by Fadila and Soedijono (2012) that respondent who have unharmonic family have 2.09 times of risk sex more than teenager harmonic family [7]. Other research also finds that respondent with incompleted family have $3.75 \%$ times have risk sex than teenager in completed family (95\% CI=1.71-6.38) [8]. Podhisita, et al. [9], bad relationship with parents or siblings and the less family control is the risk factor of sex before marriage, besides economical support, trust in God and sexual awareness [9].

Farahani, et al [10] said that to lessen the opportunity of teenager doing sex before marriage, it requires the closeness and good relationship with their family and parent's control, when the children leave home and live separated from their parents it will enlarge the opportunity of free sex [10]. Anisa and Hari (2013) states that information of reproduction health and parents are factors which affect sex before marriage of teenager of scavenger in Surabaya, besides other factor such as mate factor and mass media factor [11].

Cheryl and Claudia [12], Hanim, et al [13] and Oladipupo (2014), state their research finding that parent's role is very important for teenager [12]-[14]. According to Sarlito (2010), theoretically, unopened communication between parents and their children about sexuality and inability parents and their attitude in discussing about sex are the factors influence the teenager sexual problem [15].

\section{CONCLUSION AND RECOMENDATION}

\subsection{Conclusion}

In educational function of family is Majority family do not discuss about sex with their children (63.8\%), family do not give information about adolescent $(55.3 \%)$ and family do not explain about adolescent process $(61.7 \%)$. In Affection function known is respondent said that they feel their family do not warmth and comfortable (48.9\%), respondent do not get concern about their problems $(68.1 \%)$ and family give the negative view (forbidden thing) about sex. In Socialization function known is majority family do not give the children's need (87.2\%), family do not give control (57.4\%), do not give the think of future (53.2\%), family do not discuss about sex with their children (78.7\%). And in protection function of family known is majority family are not protective $(72.3 \%)$ and majority family give knowledge about religion and norm $(66 \%)$.

The Premarital Sex of Behavior in TWB Community majority have do sexual intercourse (68.08\%), then consecutively do masturbation $(10.63 \%)$, touching the sensitive spot $(8.51 \%)$, holding hands $(6.38 \%)$, kissing $(4.25 \%)$, and hugging $(2.12 \%)$.

\subsection{Recomendation}

For Government Health Department of Yogyakarta, this research finding is one of input to a program related to effort of improving the family health especially parents in building the teenager health reproduction, in order to avoid sex before marriage. And For Public Health center of Wirobrajan and PIR KRR in Wirobrajan sub District, it is a input of target which needs the developing in teenager reproduction health in its area.

\section{REFERENCES}

[1] R. M. Berns, "Child, Family, School, Community: Sosializations and Support," $5^{\text {th }}$ ed, Forth Worth, Hartcourt Brace College Publishers, 2004.

[2] J. Skripsiadi E., "Sex Education for Child (Pendidikan Dasar Seks untuk Anak)," Yogyakarta, Curiosita, 2005.

[3] Rakhmat, "Psychology Communication (Psikologi Komunikasi)," Bandung, PT. Rosdakarya, 2000.

[4] Dwinjandono, "Sex Education for Adolescent (Pendidikan Seks Remaja)," Jakarta, Indeks, 2008.

[5] Badan Kependudukan dan Keluarga Berencana Nasional, "Survei Demografi Kesehatan Indonesia 2012,” Jakarta, BPS, BKKBN, Kemenkes and ICF International, 2013.

[6] Pilar-PKBI, "Adolescent, Porn, and Sex Education (Remaja, Pornografi dan Pendidikan Seks)," PKBI Jateng, 2012. 
[7] F. O. S. Banun \& S. Setyorogo, "The Risk Factor of Premarital Sex at University Student Part V in STIKes X Jakarta Timur 2012 (Faktor - Faktor yang Berhubungan dengan Perilaku Seksual Pranikah pada Mahasiswa Semester V STIKes X Jakarta Timur 2012),” Jurnal Ilmiah Kesehatan, vol/issue: 5(1), pp. 12-19, 2012.

[8] Dien G. A. N., "The Risk Factor of sexual behavior at High School students SMU Negeri in Padang 2017 (FaktorFaktor yang Berhubungan dengan Perilaku Seksual Murid SMU Negeri di Kota Padang Tahun 2007)," Jurnal Kesehatan Masyarakat, vol/issue: II (2), 2012.

[9] C. Podhisita, et al., "The Risk of Premarital Sex among Tahi Youth: Individual ang Family Influences," East-West Center Working Papers Population Series, vol/issue: 108(5), 2001.

[10] Farahani F. K. A., et al., "Associations Between Family Factors and Premarital Heterosexual Relationship Among Female College Student in Tehran," International prespectives on sexual and reproductive health, vol/issue: 37(1), 2011.

[11] S. A. Pratiwi \& Hari B. N., "Factors associated with sexual behavior premarital adolescent community scavengers in Surabaya," Jurnal Biometrika dan Kependudukan, vol/issue: 2(1), pp. 10 - 17, 2013.

[12] Cheryl L. \& C. Anagurthi, "Parents' attitudes about adolescents' premarital sexual activity: The role of inter-parent consistency/inconsistency in sexual outcomes," Environmental \& Occupational Health (SSCI), vol. 112, 2014.

[13] Hanin S. H., et al., "Factors Relating to Premarital Pregnancy Amongst Muslim Adolescents in Malaysia," Research Journal of Medical Sciences, vol/issue: 6(6), pp. 266-271, 2012.

[14] B. O. O. Okorie, "Influence of Family Characteristics and Cultural Norms or Pre-marital Sex Among Secondary School Students in Ojo Local Government Area of Lagos State, Nigeria," European Scientific Journal, vol/issue: 10(5), 2014. ISSN: $1857-7881$.

[15] BKKBN, "Immediacy to have family for adolescent (Penyiapan Kehidupan Berkeluarga Bagi Remaja)," Direktorat Remaja dan Perlindungan Hak - hak Reproduksi, Jakarta, 2010. 